\title{
A Comparison of Different PCR-Based Methods for the Detection of African Horsesickness Virus
}

\author{
C.W. Bremer*
}

Agricultural Research Council-Onderstepoort Veterinary Institute (ARC-OVI), Private Bag X05, 0110 Onderstepoort, South Africa

\begin{abstract}
Detection of African horsesickness virus (AHSV) by three different reverse transcription polymerase chain reaction (RT-PCR) based methods were compared. Primers were complementary to sequences contained in the gene encoding non-structural protein 2 of AHSV serotype 3. All three assays were group-specific for AHSV and detected all nine serotypes but not related orbiviruses. A dilution range was made of titrated chicken embryo-related cells infected with AHSV serotype 3 and, after isolating RNA from each diluted sample they were tested using the three different assays. RNA representing 0.2, 2 and 20 plaque forming units of AHSV could be detected by hemi-nested RT-PCR, PCRenzyme-linked immunosorbent assay (PCR-ELISA) and RT-PCR respectively. In twelve samples from African horsesickness suspect field cases hemi-nested RT-PCR, intra-cerebral injection of mice and virus isolation from cell culture detected AHSV in $83 \%, 58 \%$ and $25 \%$ of samples respectively.
\end{abstract}

Keywords: African horsesickness virus (AHSV), polymerase chain reaction (PCR), reverse transcription PCR (RT-PCR), hemi-nested PCR, PCR-ELISA.

\section{INTRODUCTION}

African horsesickness (AHS) is a seasonal disease of mainly equines, enzootic in sub-Saharan Africa. Mortality rates as high as $93 \%$ have been reported in horses [1]. African donkeys and zebra can become infected but are usually resistant to the disease [1]. Dogs can also be infected and can develop disease [2,3]. Clinical signs are hyperthermia, oedema of the lungs, pleura and subcutaneous tissues and haemorrhages in internal organs [4].

Occasionally outbreaks occur in regions outside of Africa as a result of the introduction of infected equids, as was illustrated in the outbreak in 1987 where the source of infection was thought to be five zebras imported from Namibia to the Madrid area of Spain [5, 6]. Another possible mechanism of spread to non-enzootic regions is the dissemination of insect vectors. This was thought to have been the cause of the transmission of AHSV from Morocco to Spain in 1966, from Turkey to Cyprus in 1960 and from Senegal to the Cape Verde islands in 1943 [7]. The vectors of the disease were shown to be Culicoides biting midges of the family Ceratopogonidae [8].

The aetiological agent, African horsesickness virus (AHSV), is a member of the Orbivirus genus (family Reoviridae). The virus contains a segmented dsRNA genome consisting of 10 segments, encoding seven structural proteins and at least three non-structural (NS) proteins [9-12].

In South Africa clinical signs induced by a related orbivirus, viz. equine encephalosis virus (EEV) can be

\footnotetext{
*Address correspondence to this author at the Biotechnology Division, Agricultural Research Council-Onderstepoort Veterinary Institute, Private Bag X05, 0110 Onderstepoort, South Africa; Tel: +27 12 5299254/252; Fax: +27 12 5299249;

E-mails: vroonw@arc.agric.za, romitom@arc.agric.za
}

confused with that of AHS. Diagnostic tests should therefore be able to discriminate between these two viruses [13]. Equine encephalosis is characterised by a high morbidity $(60-70 \%)$ and a low mortality (5\%) [14].

As the spread of AHS should be controlled, identification of the virus in infected animals and in vectors is essential.

Reverse transcription (RT) of RNA followed by the polymerase chain reaction (PCR) [15] has almost totally replaced classical methods such as the intra cerebral injection of mice and inoculation in cell culture [16]. RTPCR-based methods used to effectively identify infected animals play an important role in the control of the disease. The risk of importation of infected horses or natural reservoirs of the virus such as zebra can be limited in this way. Furthermore, information regarding the prevalence of AHSV in Culicoides midges collected from the field could be invaluable for epidemiological surveillance.

Various RT-PCRs based on sequences contained in conserved genes of AHSV have been described since 1990. The genes that have been targeted are L3 encoding VP3 [17, 18]; M5 encoding non-structural protein 1 (NS1) [19]; S7 encoding VP7 [20] and S8 encoding NS2 [21-23]. Furthermore, an RT-PCR that allowed identification of the nine different AHSV serotypes based on restriction patterns of gene S10 encoding NS3 was developed [24]. The use of a hemi-nested RT-PCR based on the NS2 gene was also described [25] and recently a nested RT-PCR was developed using primers based on the L3 gene [26].

The development of real-time RT-PCR has allowed the virus to be detected more rapidly with a high degree of sensitivity. The assay also has less potential for contamination [27]. Different genes have been targeted viz. the NS1 gene [28], the VP 7 gene [27, 29, 30] and the NS2 gene [27, 31]. Real-time PCRs that allowed serotyping of the 
nine different reference strains of AHSV were also developed but some field strains contained nucleotide substitutions in the regions targeted by the primers and that resulted in small melting temperature shifts [32].

Despite the convenience of the use of real-time RT-PCR for the analysis of a large number of samples (e.g. in the case of an outbreak) many laboratories do not have the necessary facilities and capacity to do real-time PCR. The aim of this study was to improve the detection level of the RT-PCR and two different methods were investigated. Previously, the sensitivity of the RT-PCR was increased by performing Southern blot hybridisation with a ${ }^{32} \mathrm{P}$ radio-labelled probe [22]. The procedure is, however, not suitable for the routine diagnosis of AHSV because of the hazardous nature of the probe and the requirement for special facilities to perform procedures.

In the present study the level of detection of AHSV by RT-PCR and two methods, hemi-nested RT-PCR and PCRenzyme-linked immunosorbent assay (PCR-ELISA) that increase the level of virus detection, were compared. These methods are based on detection by RT-PCR amplification of the S8 gene of AHSV that is conserved in the AHSV serogroup [33]. Hereafter, detection of AHSV in field samples of suspect cases by hemi-nested PCR and virus isolation procedures were compared.

\section{MATERIALS AND METHODOLOGY}

\subsection{Cells, Virus and Virus Isolation}

AHSV stocks were obtained from Dr. B.J. Erasmus, then from Onderstepoort Biological Products and equine encephalosis (EEV) stocks (serotypes Bryanston, Cascara, Gamil, Kaalplaas, Kyalami and Potchefstroom ) from Prof. P. Howell, then from the Tropical Diseases Department of the Faculty of Veterinary Science of the University of Pretoria. These were cultivated as described [23]. Bluetongue virus serotype 10 (BTV10) and epizootic haemorrhagic disease of deer virus New Jersey strain (EHDV-NJ) were obtained from Mr R. Greyling then of the Agricultural Research Council-Onderstepoort Veterinary Institute (ARCOVI). AHSV and EEV serotypes were cultivated as described previously [23]. BTV was passaged once in an embryonated egg, at least 6 times in baby hamster kidney cells and then in chicken embryo reticulum (CER) cells (developed by Tsunemasa Motohashi, Nipon Institute, Japan). EHDV-NJ was cultivated once in BHK cells and thereafter five times in CER cells. Virus was isolated from the spleens of field samples a described [23]. Monolayers of Vero cells were seeded with a $10 \%(\mathrm{w} / \mathrm{v})$ suspension of macerated spleens in buffered lactose peptone. After a 15 min incubation period, cells were washed three to four times in Eagle's medium and grown in Eagle's medium. Both buffered lactose peptone and Eagles medium contained standard concentrations of antibiotics and amphotericin. Cells were monitored for cytopathic changes on a daily basis. Appropriate volumes of the same suspensions were used to inoculate infant mice and mice were daily observed for clinical signs [23]. RNA samples used for sensitivity determination were extracted from identical volumes of a dilution range made from AHSV-3 infected cell cultures [23].

\subsection{RNA Extraction}

Total RNA was extracted from the different infected CER cell samples and from blood and organ samples as described [23, 34]. In short: a suspension was made of approximately $300 \mu \mathrm{g}$ of organs or of the blood cell pellet obtained from $1 \mathrm{ml}$ of blood. To this were added $500 \mu \mathrm{l}$ solution D (4M guanidium thiocyanate, $25 \mathrm{mM}$ sodium citrate, $\mathrm{pH} 7,0.5 \%$ sarkosyl and $0.1 \mathrm{M} \beta$-mercapto ethanol), $50 \mu 1$ of $2 \mathrm{M}$ sodium acetate ( $\mathrm{pH} 4), 500 \mu 1$ water saturated phenol and $100 \mu 1$ chloroform:isoamyl alcohol (49:1). Samples were centrifuged at $18000 \mathrm{xg}$ for $15 \mathrm{~min}$ and the RNA in the supernatant fluid was precipitated with isopropanol. Pellets were washed in $75 \%$ ethanol and resuspended in water.

\subsection{RT-PCR}

$\mathrm{RT}$ and PCR reactions were performed sequencially in a single tube as described [23]. Total extracted RNA was added to $50 \mathrm{ng}$ of each of forward primer OP72 (5'TGGCACGAAGACATG-3') and reverse primer OP73 (5'CTCTCATCGCCAATG-3') (Table 1). The volume was adjusted to $5 \mu 1$ with pyrogen free water, heated for $3 \mathrm{~min}$ at $96^{\circ} \mathrm{C}$ and cooled on ice. To this was added a $5 \mu$ volume of a mixture containing $10 \mathrm{U}$ Moloney murine leukemia virus reverse transcriptase (M-MLV RT) (Promega Madison, Wisconsin), 2x M-MLV-RT buffer and $10 \mathrm{mM}$ of each dNTP and approximately $25 \mathrm{U}$ human placental RNase inhibitor (GE Healthcare, Little Chalfont, England). Samples were incubated at $37^{\circ} \mathrm{C}$ for $45 \mathrm{~min}$. To this sample $40 \mu 1$ of a mixture containing 2U DNA Dynazyme ${ }^{\mathrm{TM}}$ (Finnzymes, Vantaa, Finland), $1.2 \times$ Dynazyme buffer and $200 \mu \mathrm{M}$ of each dNTP was added. The PCR was performed using the following conditions: $96^{\circ} \mathrm{C}$ for $3 \mathrm{~min}$, and 40 cycles of $96^{\circ} \mathrm{C}$ for $20 \mathrm{~s}, 57^{\circ} \mathrm{C}$ for $30 \mathrm{~s}$ and $72^{\circ} \mathrm{C}$ for $30 \mathrm{~s}$. The PCR products were analysed by electrophoresis in a $1.5 \%$ agarose gel containing ethidium bromide. DNA was visualised by UVirradiation.

\subsection{Testing for Inhibitors of RT-PCR in Cell Culture Samples}

To ascertain the absence of substances inhibiting RTPCR in the RNA samples from the related orbiviruses, duplicate samples of total RNA isolated from CER cells infected with EHDV-NJ, BTV10 and six EEV serotypes Bryanston, Cascara, Gamil, Kaalplaas, Kyalami and Potchefstroom were prepared. One of each of the two samples was spiked with a sample identical to the positive control sample which consisted of total RNA isolated from AHSV-3 infected cells. The RT-PCR was performed as described above and PCR products were analysed by agarose gel electrophoresis as described above to determine whether inhibition of the RT-PCR had occurred.

\subsection{Hemi-Nested PCR}

An internal primer CV6 (5'-AGAGTATGTGGTGTC-3') (Table 1) comprising sequences contained in a conserved region of the AHSV 3 NS2 gene, was designed. This was used in combination with the reverse primer (OP 73) used in the original RT-PCR to prime the hemi-nested PCR. The hemi-nested PCR was performed in 1 x Dynazyme buffer, $200 \mu \mathrm{M}$ of each of dATP, dCTP, dGTP and dTTP, $0.04 \mathrm{U} /$ $\mu 1$ Dynazyme, 0.4 pmole/ $\mu 1$ of each of primers OP73 and 
primer CV6. To this $4 \mu \mathrm{l}$ of a RT-PCR product diluted $20 \mathrm{x}$ in water was added. The final reaction volume was $25 \mu \mathrm{l}$. Conditions at which the hemi-nested PCR was performed was as follows: $96{ }^{\circ} \mathrm{C}$ for 30 s followed by 30 cycles of $96{ }^{\circ} \mathrm{C}$ $20 \mathrm{~min}, 57^{\circ} \mathrm{C} 30 \mathrm{~s}, 72^{\circ} \mathrm{C} 30 \mathrm{~s}$.

\subsection{PCR-ELISA}

The PCR-ELISA was performed using the PCR-ELISA kit (Roche, Penzberg, Germany). A 5'-biotin-labelled oligonucleotide probe, CV1 (5'-B-CTGAGTTGGTGGAGA TGGAG-3') and a 5'-digoxygenin-labelled oligonucleotide probe CV5-dig (5'-Dig-ATCTGATGAGGATCACGAGG3') (Table 1) containing sequences complementary to the negative strand of AHSV NS2 dsRNA, were hybridised to RT-PCR amplicons. The hybrid biotin-labelled oligo probe/amplicon was captured on a streptavidin coated microtitre plate. The digoxygenin-labelled oligo probe that hybridised to the same strand of the amplicon, was detected by anti-digoxygenin antibodies conjugated to peroxidase. The reaction was visualised by the addition of 2, 2'-Azinobis [3-ethylbenzothiazoline-6-sulfonic acid]-diammonium salt (ABTS) substrate in the kit. Samples were considered positive if their values were twice the average OD ${ }_{\text {A405-492 }}$ reading of the negative control samples (water) plus $3 \mathrm{x}$ standard deviation.

\section{RESULTS AND DISCUSSION}

Table 1 shows primer and probe sequences based on the NS2 gene of an isolate of AHSV3 (GenBank accession number AF 545434) aligned to that of a similar region of the NS2 genes of isolates of eight different AHSV serotypes obtained from GenBank (Table 1). In the RT-PCR forward and reverse primers, as well as in the digoxygenin-labelled probe, a maximum of two basepair (bp) nucleotide mismatches was observed. In the biotin-labelled probe a maximum of one bp mismatch was observed whereas the hemi-nested primer was identical in all the included isolates of different serotypes.

Despite the small number of nucleotide bp differences in the primer regions, all nine different serotypes were detected. Sequencing of southern African isolates showed that AHSV NS2 gene is more conserved than the VP7 and the NS1 genes [27].

To ascertain that the negative results obtained with the related viruses in the different RT-PCR-based procedures were not due to the presence of inhibitors of PCR such as phenol and/or detergents that might not have been completely removed during the RNA extraction procedure $[35,36]$, the efficiency of the RT-PCR in spiked samples were monitored. One of two samples of the negative control RNA sample and samples of six EEV serotypes, EHDV-NJ and BTV10 were spiked with AHSV3 RNA and subjected to amplification by RT-PCR as described above. After agarose gel electrophoresis, an AHSV3-specific RT-PCR amplicon of $230 \mathrm{bp}$ was observed in each spiked sample but not in the samples without AHSV3 RNA. Inhibition would have been indicated if the RT-PCR band of the spiked sample was either absent or weaker than that of the positive control sample (data not shown). The negative results were assumed to be as a result of lack of sequence similarity between the S8 genes of the different viruses.
The serogroup reactivity of the RT-PCR had been described previously; all AHSV serotypes but none of the EEV serotypes were detected [23]. The RT-PCR could detect RNA representing 20 plaque forming units (PFU) of AHSV3 (Fig. 1).

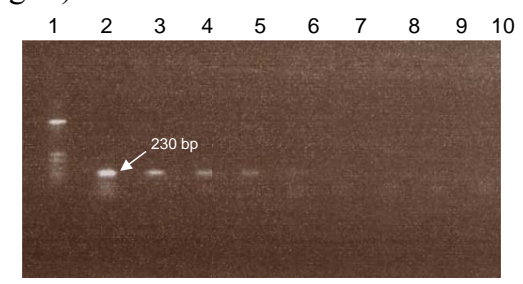

Fig. (1). Agarose gel electrophoresis of RT-PCR amplicons. In the different lanes are Hinf 1 digested pAT 153 molecular mass marker (lane 1), positive AHSV3 control (lane 2), 20000 PFU AHSV3 (lane 3), 2000 PFU AHSV3 (lane 4), 200 PFU AHSV3 (lane 5), 20 PFU AHSV3 (lane 6), 2 PFU (lane 7), 0.2 PFU (lane 8), 0.02 PFU (lane 9) negative control (lane 10).

In order to improve the sensitivity of the RT-PCR, the use of PCR-ELISA was invesigated. The nine AHSV serotypes, six EEV serotypes, EHDV-NJ and BTV-10 samples were tested by PCR-ELISA to determine the AHSV group-reactivity of the PCR-ELISA. The probes detected only the RT-PCR products of the AHSV serogroup at OD A405-492 (Fig. 2). All AHSV serotypes and the AHSV3 positive control samples were positive whereas the EHDVNJ, BTV10, the six EEV serotypes and negative control samples were negative. Despite the single nucleotide base mismatch in regions targeted by the biotinylated probe for serotypes 5-8 and the digoxygenin-labelled probe for serotypes 2, 4 and 5 and of two base mismatches in the digoxygenin-labelled probe for serotypes 6 and 7 , the reaction was AHSV serogroup-specific.

The PCR-ELISA was performed as described in Materials and Methodology and AHSV3 was detected in a sample representing 2 PFU of AHSV3 (Fig. 3).

The serogroup reactivity of the RT-PCR had been determined previously [23]. In order to confirm the serogroup-reactivity of the hemi-nested PCR and to ensure that the primers detect all nine serotypes, the reaction was performed on purified RNA from cells infected with AHSV serotypes 1-9, six EEV serotypes as well as EHDV-NJ and BTV10 respectively. No $159 \mathrm{bp}$ fragment was observed in RNA samples of six of the EEV serotypes, EHDV-NJ, BTV10 and negative control samples (data not shown) whereas a 159 bp fragment was seen in each of the nine AHSV serotypes.

The hemi-nested RT-PCR could detect RNA in the sample representing 0.2 PFU of AHSV-3 (Fig. 4). The presence of defective interfering particles and other noninfectious particles as well as mRNA which are not reflected by the number of PFUs could possibly be the cause. The level of detection of the hemi-nested RT-PCR compared favourably with results obtained in the methods described by those of other investigators. The detection level is, however, 40 times lower than detection by RT-PCR followed by Southern blot hybridisation using a radio-labelled probe [23]. The method using a radio-active probe could also detect virus in an experimentally infected horse from day three up 
Table 1. Primer and Probe Alignment of the NS2 Gene Sequences Used for RT-PCR Based Detection of AHSV. The Sequence of One Isolate of Each Serotype was Aligned to that of AHSV3. Forward and Reverse Primers (A), Hemi-Nested Primer (B) and Biotin- and Digoxigenin-Labelled Probes (C). The GENBANK Accession Number of the Isolate Used for Each Serotype is Shown

\section{A}

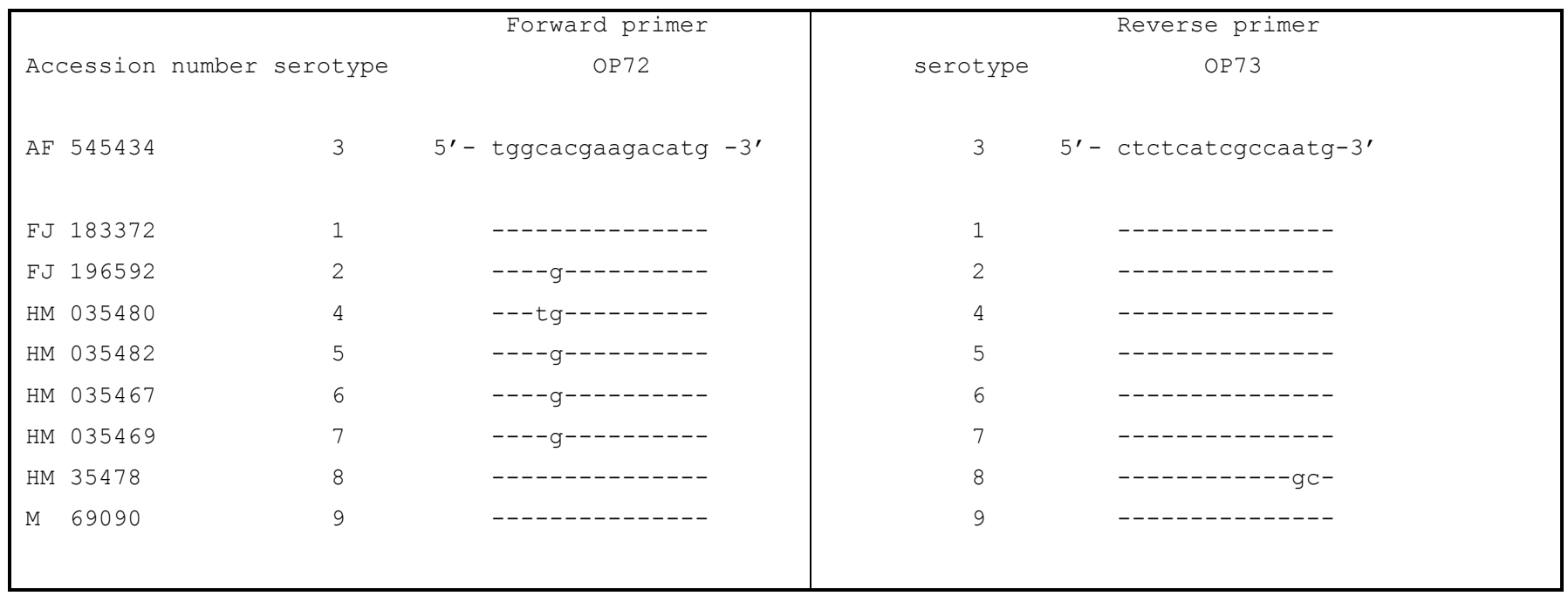

B

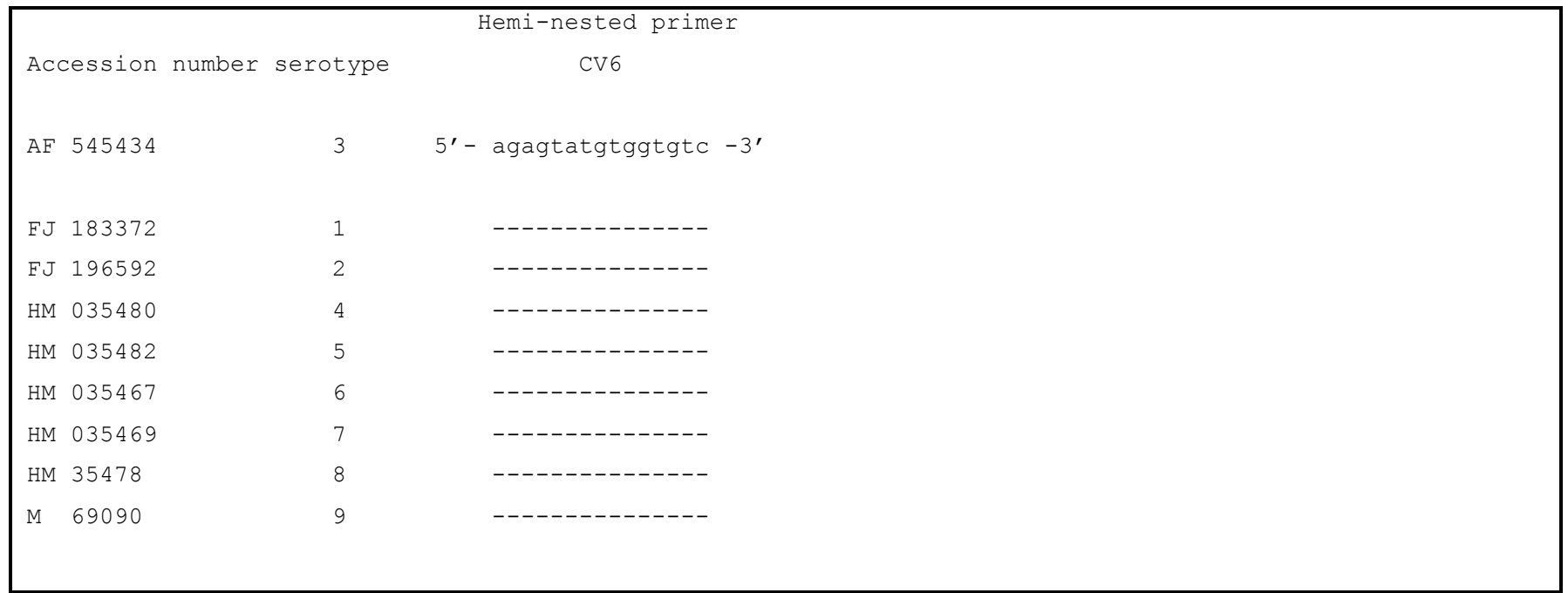

C

\begin{tabular}{|c|c|c|c|c|c|}
\hline \multirow{2}{*}{\multicolumn{2}{|c|}{ Accession number }} & \multirow[b]{2}{*}{ serotype } & Biotin-labelled primer & \multicolumn{2}{|r|}{ Digoxygenin-labelled primer } \\
\hline & & & CV1 & serotype & CV5-dig \\
\hline & 183372 & 1 & -------------------- & 1 & ---------- \\
\hline & 196592 & 2 & -----1 & 2 & ---------- \\
\hline & 035480 & 4 & -------------- & 4 & $-------------------\mathrm{a}$ \\
\hline & 035467 & 6 & $----------a---------$ & 6 & $---------a---------a$ \\
\hline & 035469 & 7 & --- & 7 & $---------a---------a$ \\
\hline & 35478 & 8 & $----------a---------$ & 8 & -------------------- \\
\hline M & 69090 & 9 & -------------------- & 9 & -------------- \\
\hline
\end{tabular}


to 22 weeks (154 days) post infection [23]. Real-time PCR could detect virus in a different experimentally infected horse from 7 up to 97 days post infection using real-time PCR [27].

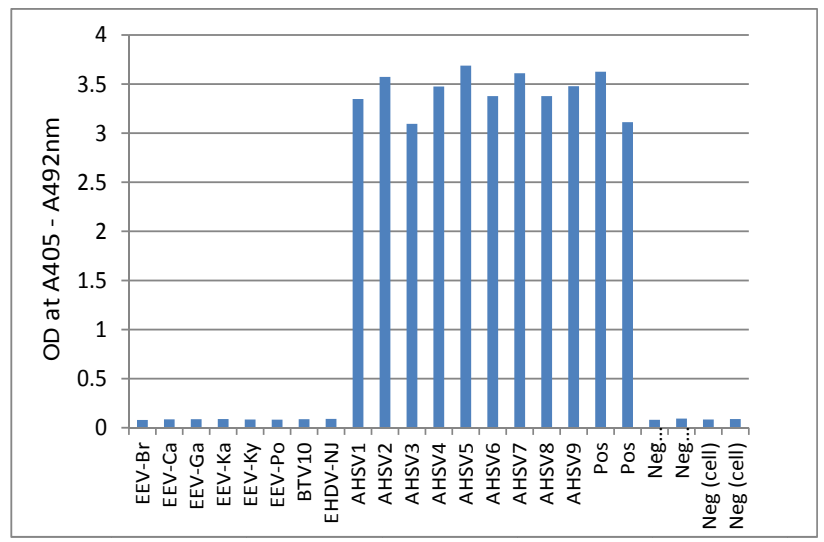

Fig. (2). OD values at $A_{(405-492)}$ of $A H S V$ and EEV serotypes, EHDV-NJ and BTV10 obtained with PCR-ELISA.

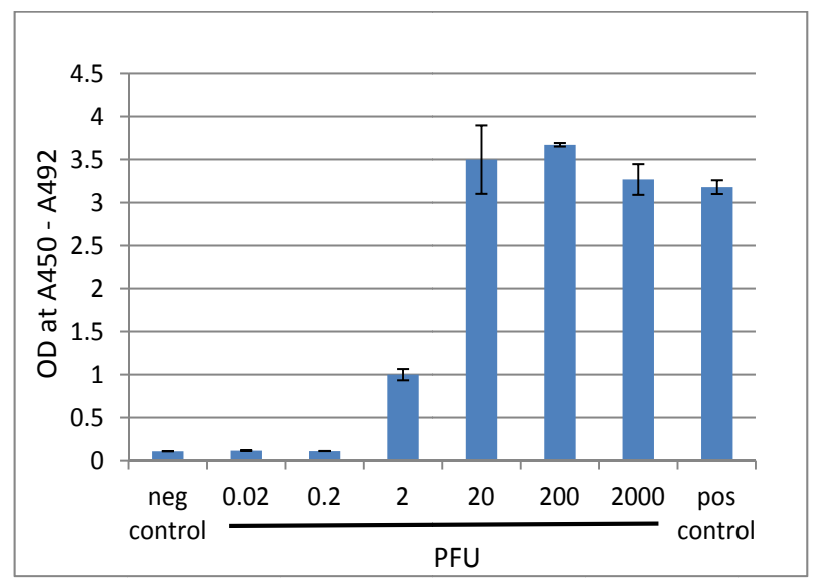

Fig. (3). Detection of AHSV3 RNA in samples with titres ranging from 0.02 to $200 \mathrm{PFU} / \mathrm{ml}$ using PCR-ELISA. OD values at $\mathrm{A}_{(405}$ 492) are indicated.

The level of detection of AHSV by real-time PCR has been determined by different groups: RNA was detected in samples containing $0.1 \mathrm{TCID}_{50} / \mathrm{ml}$ using $\mathrm{SyBr}^{\mathrm{TM}}$-Green and $1.2 \mathrm{TCID}_{50} / \mathrm{ml}$ when using Taqman probes [28] and RNA could be detected in samples with concentrations varying between 0.18 and $51 \mathrm{TCID}_{50} / \mathrm{ml}$ for the nine different AHSV serotypes [29]. In another instance between 0.001 and 0.15 $\mathrm{TCID}_{50}$ could be detected in samples of the nine AHSV isolates [30]. Another group detected detected 132 and 114 particles when using VP7 and NS2 probes respectively [27]. In one instance real time PCR could detect 5 pg AHSV RNA [32]. When using nested RT-PCR based on genome L3 of AHSV-6, $0.1 \mathrm{fg}$ of viral RNA could be detected [18].

Hemi-nested RT-PCR was also compared with the detection of virus in suspect field cases by virus isolation in cell cultures and intra-cerebral inoculation of suckling mice. Twelve samples were tested and 3, 7 and 10 samples were positive by cell culture isolation, intra cerebral inoculation of mice and hemi-nested RT-PCR respectively (Table 2). In one case virus could be isolated by injection of suckling mice but could not be detected by hemi-nested PCR. The effect of degeneration of virus outer capsid proteins during storage of specimens at $4^{\circ} \mathrm{C}$ during transport could possibly affect the infectivity of the virus.
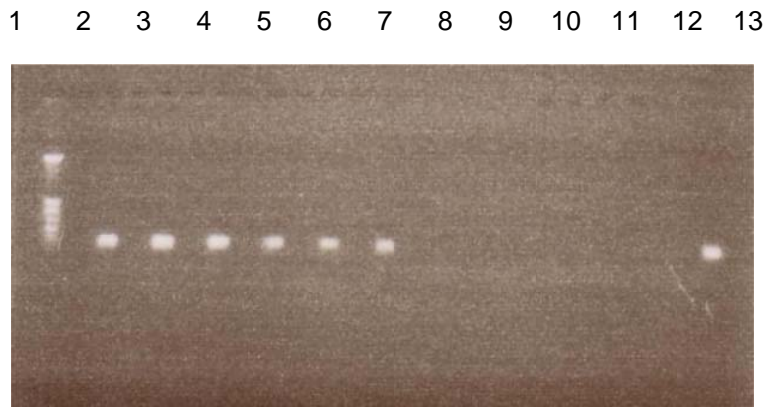

Fig. (4). Agarose gel electrophoresis of hemi-nested RT-PCR amplicons. In the different lanes are Hinf 1 digested pAT 153 molecular mass marker (lane 1), 20000 PFU AHSV3 (lane 2), 2000 PFU AHSV3 (lane 3), 200 PFU AHSV3 (lane 4), 20 PFU AHSV3 (lane 5), 2 PFU (lane 6), 0.2 PFU (lane 7), 0.02 PFU (lane 8), negative controls (lanes 9-12) AHSV3 positive control (lane 13).

Table 2. Comparison of Detection of Virus in Twelve Suspect Field Cases by Virus Isolation Using Vero Cells, Inoculation into Mouse Brain and Hemi-Nested PCR

\begin{tabular}{|c|c|c|c|}
\hline Number & Cell Culture & Mice & Hemi-Nested PCR \\
\hline \hline HS 51 & - & - & + \\
\hline HS 59 & - & - & + \\
\hline HS 62 & - & - & + \\
\hline HS 64 & + & + & + \\
\hline HS 66 & + & + & + \\
\hline HS 69 & + & + & + \\
\hline HS 77 & - & + & + \\
\hline HS 78 & - & + & + \\
\hline HS 90 & - & - & - \\
\hline HS 91 & - & + & - \\
\hline HS 92 & - & - & + \\
\hline HS 93 & - & + & + \\
\hline
\end{tabular}

The time in which the hemi-nested PCR can be completed is approximately 5-6 hr. This is considerably longer than the $2 \mathrm{~h}$ using Taqman probes and $2.5 \mathrm{~h}$ when using $\mathrm{SYBR}^{\mathrm{TM}}$-Green dye [34]. A result can, however, still be obtained within a working day. The time of the reverse transcription, denaturation, annealing and extension steps of both RT-PCR and hemi-nested RT-PCR can most likely be shortened without having an effect on the detection level of the test. The use of random hexamers in the reverse transcription reaction was found to increase the level of detection [27] and could possibly also improve the level of detection of the described hemi-nested RT-PCR. Although amplicon contamination could potentially occur, it was not found to be a problem in the ARC-OVI diagnostic PCR laboratory, probably as a result of the small number of samples that were tested on an intermittent basis and 
separate spaces in which the different reaction mixes were assembled.

Real-time RT-PCR has been shown to be a rapid effective method for the detection of AHSV [27-32]. There is, however, still a place for the detection of the AHSV serogroup by more conventional methods such as heminested RT-PCR where real-time thermocyclers are not available. As a result of the enzootic nature of the AHS in South Africa, small numbers of samples $(n=1-4)$ are occasionally sent for diagnosis by the ARC-OVI diagnostic PCR laboratory. Fluorescent reagents used for real-time PCR have a limited life-span, are expensive and may lose their reactivity before they are completely utilised. The aim of the study was to increase the sensitivity of detection of AHSV by RT-PCR without using real-time RT-PCR or radioactively labelled probes.

The hemi-nested RT-PCR method described in this study has been used successfully on a routine basis for more than ten years to detect AHSV RNA in samples received for testing in the ARC-OVI diagnostic PCR laboratory. The nucleic acid purification procedure has now been automated. The method was found to be an effective and sensitive routine diagnostic tool for the detection of AHSV when small numbers of samples from suspect AHSV cases were tested.

\section{ACKNOWLEDGEMENTS}

The author thanks Mrs P Combrink and Mr R Greyling of the OIE Reference Laboratory for cell cultivation and virus isolation. Dr J Paweska is thanked for initiating the comparative hemi-nested PCR and virus-isolation study and Dr G. Gerdes for the interpretation and combining of virus isolation results. Drs G.J. Viljoen and B. Dungu-Kimbenga are thanked for valuable discussions and Drs G. Gerdes, M. Romito, O. Koekemoer, and P. Majiwa for reviewing the manuscript. I thank the then Department of Agriculture for funding.

\section{CONFLICT OF INTEREST}

\section{Declared None.}

\section{REFERENCES}

[1] Henning MW. African horsesickness, perdesiekte, pestis equorum. In: Animal diseases in South Africa. Pretoria: Central News Agency Ltd. 1956; pp. 581-602.

[2] Theiler A. Transmission of horsesickness into dogs. Rep Gov Vet Bact 1906; 160-2.

[3] Van Rensburg IBJ, De Clerk J, Groenewald HB, Botha WS. An outbreak of African horsesickness in dogs. J S Afr Vet Assoc 1981; 152: 323-5.

[4] Mcintosh BM. Immunological types of horsesickness virus and their significance in immunization. Onderstepoort J Vet Res 1958; 27: 466-538

[5] Lubroth J. African horse sickness and the epizootic in Spain 1987. Equine Pract 1988; 10: 26-33.

[6] Mellor PS. African horse sickness: transmission and epidemiology. Vet Res 1993; 2: 199-212.

[7] Sellers RF, Pedgley DE, Tucker MR. Possible spread of African horse sickness on the wind. J Hyg-Cambridge 1977; 79: 279-98.

[8] Du Toit RM. The transmission of Blue-tongue and Horse-sickness by Culicoides. Onderstepoort J Vet Sci Anim Ind 1944; 19: 7-16.

[9] Bremer CW. A gel electrophoretic study of the protein and and nucleic acid components of African horsesickness virus. Onderstepoort J Vet Res 1976; 43: 193-200.

[10] Grubman MJ, Lewis SA. Identification and characterization of the structural and non-structural proteins of African horsesickness virus and determination of the genome coding assignments. Virology 1992; 186: 444-51.

[11] Laviada MD, Arias M, Sánchez- Vizcaíno JM. Characterization of African horsesickness serotype-4 polypeptides in Vero cells and their reactivity in Western immunoblotting. J Gen Virol 1993; 74: 81-7.

[12] Roy P, Mertens PP, Casal I. African horse sickness virus structure. Comp Immunol Microbiol Infect Dis 1994; 17: 243-73.

[13] Viljoen GJ, Huismans $H$. The characterization of equine encephalosis virus and the development of genomiprobes. J Gen Virol 1989; 70: 2007-15.

[14] Coetzer JAW, Erasmus BJ. In: Coetzer JAW, Thomson GR, Tustin RC, Kriek NPJ. Eds. Infectious Diseases of Livestock with special reference to Southern Africa. Southern Africa, Cape Town: Oxford University Press 1994; pp. 476-9.

[15] Saiki RK, Scharf S, Faloona F, et al. Enzymatic amplification of beta-globin genomic sequences and restriction site analysis for diagnosis of sickle cell anemia. Science 1985; 230: 1350-4.

[16] Rodriguez M, Hooghuis H, Castaňo M. African horse sickness in Spain. Vet Microbiol 1992; 33: 129-42.

[17] Sakamoto K, Punyahotra R, Mizukoshi N, et al. Rapid detection of African horsesickness virus by the reverse transcriptase polymerase chain reaction (RT-PCR) using the amplimer for segment 3 (VP3 gene). Arch Virol 1994; 36: 87-97.

[18] Aradaib IE, Mohemmed MEH, Sarr JA, et al. A simple method for detection of African horse sickness virus serogroup in cell cultures using RT-PCR. Vet Res Commun 2006; 30: 319-24.

[19] Mizukoshi N, Sakamoto K, Iwata A, et al. Detection of African horsesickness virus by reverse transcriptase polymerase chain reaction (RT-PCR) using primers for segment 5 (NS1 gene). J Vet Med Sci 1994; 56: 347-52.

[20] Zientara S, Sailleau C, Moulay S, Cruciere C. Diagnosis of the African horse sickness virus serotype 4 by a one-tube, one manipulation RT-PCR reaction from infected organs. J Virol Methods 1994; 46: 179-88.

[21] Stone-Marschat M, Carville A, Skowronek A, Laegreid WW. Detection of African horse sickness by reverse-transcription-PCR. J Clin Microbiol 1994; 32: 697-700.

[22] Bremer CW, Viljoen GJ. RT-PCR detection of the African horsesickness virus serogroup. In: Schwyzer M, Ackermann M. Edsin-chief. Proceedings of the $3^{\text {rd }}$ Congress of the European Society for Veterinary Virology. Lyon: Fondation Marcel Mérieux Publishers 1995; pp. 331-6.

[23] Bremer CW, Viljoen GJ. Detection of African horsesickness virus and discrimination between two equine orbivirus serogroups by reverse transcription polymerase chain reaction. Onderstepoort J Vet Res 1998; 65: 1-8.

[24] Zientara S, Sailleau C, Moulay S, Cruciere, C. Differentiation of African horse sickness viruses by polymerase chain reaction and segments 10 restriction patterns. Vet Microbiol 1995; 47: 365-75.

[25] Bremer CW, Dungu-Kimbenga B, Viljoen GJ. Detection of African horse sickness virus in zebra by RT-PCR and the development of different methods for confirming AHSV specificity of RT-PCR products. In: Wernery U, Wade JF, Mumford JA, Kaaden O-R, Eds. Equine Infectious Diseases VIII. Proceedings of the $8^{\text {th }}$ International Conference. Suffolk: R \& W Publishers (Newmarket) Ltd, 1998; 529. Aradaib IE. PCR detection of African horse sickness serogroup based on genome segment three sequence analysis. J Virol Methods 2009; 159(1): 1-5.

[27] Quan M, Lourens CW, Maclachlan NJ, Gardner IA, Guthrie AJ. Development and optimisation of a duplex real-time reverse transcription quantitative PCR assay targeting the VP7 and NS2 genes of African horse sickness virus. J Virol Methods 2010; 167: 45-52.

[28] Rodriguez-Sanchez B, Fernandez-Pinero J, Sailleau C, et al. Novel gel-based and real-time PCR assays for the improved detection of African horse sickness virus. J Virol Methods 2008; 151: 87-94.

[29] Agüero M, Gómez-Tejedor C, Angeles Cubillo M, Rubio C, Romero E, Jiménez-Clavero A. Real-time fluorogenic reverse transcription polymerase chain reaction assay for detection of African horse sickness virus. J Vet Diagn Invest 2008; 20: 325-8.

[30] Fernández-Pinero J, Fernández-Pacheco $\mathrm{P}$, Rodríguez $\mathrm{B}$, et al. Rapid and sensitive detection of African horse sickness virus by real-time PCR. Res Vet Sci 2009; 86: 353-8. 
[31] Monaco F, Polci A, Lelli R, et al. A new duplex real-time RT-PCR assay for sensitive and specific detection of African horse sickness virus. Mol Cell Probes 2011; 25: 87-93.

[32] Koekemoer JJ. Serotype-specific detection of African horsesickness virus by real-time PCR and the influence of genetic variations. J Virol Methods 2008; 154(1-2): 104-10.

[33] Bremer CW, Huismans H, Van Dijk AA. Characterization and cloning of the African horsesickness virus genome. J Gen Virol 1990; 71: 793-9.
[34] Chomczynski P, Sacchi N. Single-step method of RNA isolation by acid guanidium thiocyanate-phenol-chloroform extraction. Anal Biochem 1987; 162: 156-9.

[35] Weyant RS, Edmonds P, Swaminathan B. Effect of ionic and nonionic detergents on the Taq polymerase. Biotechniques 1990; 9: 308-9.

[36] Katcher HL, Schwartz I. A distinctive property of the Tth DNA polymerase : enzymatic amplification in the presence of phenol. Biotechniques 1994; 16: 84-92.

Received: September 12, 2011

Revised: November 11, 2011

Accepted: December 16, 2011

(C) C.W. Bremer; Licensee Bentham Open.

This is an open access article licensed under the terms of the Creative Commons Attribution Non-Commercial License (http: //creativecommons.org/licenses/by$\mathrm{nc} / 3.0 /$ ) which permits unrestricted, non-commercial use, distribution and reproduction in any medium, provided the work is properly cited. 